Volume 11, Issue 12, December 2020, pp. 259-268. Article ID: IJM_11_12_025

Available online at http://iaeme.com/Home/issue/IJM?Volume $=11 \&$ Issue $=12$

Journal Impact Factor (2020): 10.1471 (Calculated by GISI) www.jifactor.com

ISSN Print: 0976-6502 and ISSN Online: 0976-6510

DOI: 10.34218/IJM.11.12.2020.025

\title{
KNOWLEDGE MANAGEMENT, HUMAN CAPITAL AND ORGANIZATIONAL INNOVATION AS DRIVERS OF QUALITY HIGHER EDUCATION IN MALAYSIA: LESSONS FOR GULF COUNTRIES
}

\author{
Wan Norhayate Wan Daud and Fakhrul Anwar Zainol \\ Universiti Sultan Zainal Abidin, Terengganu, Malaysia \\ Reynaldo Gacho Segumpan \\ Ministry of Higher Education, Rustaq COE, Oman
}

\begin{abstract}
The promotion from quality of higher education in Malaysian public universities is widely documented. However, how it links to the enhancement of quality education in the Gulf Cooperation Council (GCC) Countries seems non-existent. This paper hopes to address this gap on Organizational Innovation (OI) from perspective Knowledge Management (KM) and Human Capital (HC) for Quality Higher Education in Malaysia and how it may be relevant to the GULF countries. Three faculties were chosen for this study from Malaysian Public Universities in Malaysia. Semi structure in-depth interview conducted for three deans from faculty of management from three selected universities. This study recommends the goods side of organizational innovation in Malaysian Public Universities that will also be applicable in higher education institutions in the GULF as well to GULF Countries.
\end{abstract}

Key words: knowledge management, human capital, organizational innovation, quality higher education.

Cite this Article: Wan Norhayate Wan Daud, Fakhrul Anwar Zainol, Reynoldo Gacho Segumpan, Knowledge Management, Human Capital and Organizational Innovation as Drivers of Quality Higher Education in Malaysia: Lessons for Gulf Countries, International Journal of Management, 11(12), 2020, pp 259-268.

http://iaeme.com/Home/issue/IJM?Volume=11\&Issue=12 


\section{INTRODUCTION}

\subsection{Background of the Study}

The idea of innovation's concept is always current. Many organizations intended to know how and why their business succeed, even fail. They also like to know what are the factors that influenced them to increase performance. According to Garcia'- Morales (2008) [15] postulated that organizational innovation is one of the pillar factors to improve the company's performance. Due to the latest trends in the VUCA environment nowadays are always uncertain. Many researchers found that an element of knowledge management is one of the items which will increase the firm's competence (Rania \& Wan Daud, 2019) [27]. Knowledge management is also known as valuable resources in the organization. These include the same items as land, buildings, financial resources, people, capital equipment, and other tangible assets (Kipley, Lewis \& Helm, 2008) [17]. Therefore, one of the alternatives to gain added value from the critical factors for organizational innovation is knowledge management.

Although knowledge management practice for Malaysian universities still at the development stage, but the momentum to expand it is hugely growing. The universities should highly focus on activities on campus, such as talent pool that consists of human expertise, skills, and competencies as a part of implementing knowledge management. The universities need to look as references at how the big multinational companies still lead in practicing knowledge management. Nowadays, Knowledge management is one of the essential factors for the government plans that affect the vision and mission for the country and how the government's agency operational their tasks daily (Suraya \& Jamaliah, 2005) [29].

Nonaka and Takeuchi (1995) [22] said that Knowledge management and human capital are connected. Many organizations agreed to recognize that human capital is a human asset to the firms. It not only referring to the worker personally in a company but consists of a worker's capabilities, knowledge, skills, life experiences, and motivation of the workforce (Aldisent, 2002) [1]. Human capital refers to intellectual capital, whereby it represents the thinking, knowledge, creativity, and decision making that people in organizations contribute (Kaplan \& Norton, 2004) [16].

Based on the scenario above, the objective of this study are as follows: (1) To identify factors on human capital towards organizational innovation; (2) To analyze the effects of knowledge management towards organizational innovation and (3) To recommend the framework of organizational innovation in Public Higher Education Institution. The study explores how the findings could contribute to Malaysian Public Universities, especially to the universities located at the East Coast of Peninsular Malaysia. Hopefully, this study also able to realize the linked enhancement of quality education in the Gulf Cooperation Council (GCC) Countries as a reference from Malaysian Public Universities in the East Coast of Peninsular Malaysia.

This study is structured as follows: First, a summary of the literature on the concept of Organizational Innovation, Knowledge Management, and human capital is to be thoroughly discussed. Second, the methodology and sample are both described. Third, a recapitulation of findings, and finally, the conclusion is provided by summarizing the avenues for further future research.

\section{LITERATURE REVIEW}

\subsection{Theoritical Groundwork}

Resource-Based View Theory (RBV) used as the primary theory for this study. Studies (2005) [26] stated that expanding the scope and nature of the resources to gain a competitive 
advantage in organizational innovation. In this theory, the organizational resources comprising tangible and intangible will be used as inputs, in turn of the process, will transform to produce the innovative comparative advantage of the organizations.

According to Dell Canto and Gonzalez (2005)[10], innovation can be trace from human capital to the organization's core competencies. RBV and innovation are needed for each other. It may determine the organization transforms knowledge into innovation after the firms used the RBV to the substantial improvement (Wan Daud et al., .2017) [30]

\subsection{Organizational Innovation}

Today, many scientists and researchers from different majors fields agreed that organizational innovation is of great importance to all organizations. It prevents the organization from leftbehinds from the rival and, at the same time, create additional value and maintaining the sustainability of the performance of the firm itself. Organizations that valued the significant importance of practicing innovations will act successfully in response to various situations. It can also create and develop new capabilities, which let them improve performance (Bromand \& Ranjbar, 2009) [6].

Camarero (2009) [8] viewed that developing new ideas and new behaviors can be called as organizational innovation. Damanpour (1991) [9] stated the consistency of the result on particular research based on the increasing number of innovations made. Organizational innovations can be more or less complicated. For example, when a specific business process changes, it will automatically affect every organization's output. Further, it also will create a more extensive program of the inventions. Total Quality Management (TQM) can be put as an example of implementing organizational innovation. TQM is applied to help the organization in employees' problem-solving capacity. The innovation used to concentrate on a high focus on the empowerment of employees. It is an innovation when it involves many parts of the organization, which will create a successful output.

Many researchers debate about how many dimensions of innovation. Some of them agreed that innovations consists of the two-core model comprise of technological and administrative innovations. Another view offered a multidimensional model that identifies radical innovation vs. continuous innovation, technological innovation vs. administration innovation, and product innovation vs. Process innovation. However, although there are different ways of interpreting it, many of them agreed that the innovation's dimension referred to radical, gradual, product, process, administration, and technological aspects. Thus, the more common elements among the researchers and experts about innovation are product innovation, process innovation, and administration innovation. Product innovation refers to creating new or improved existing products and services. At the same time, if the organization applied new technologies and experiments during the implementation process to improve performance, it called as process innovation. While in a situation where managers are managing administration systems, including the approaches, policies, unique structure, and administration process, which will affect the policies, resource allocations, and organizational social cultures is call as administration innovation.

\subsection{Human Capital}

Ideally, human capital refers to any situation related to attraction, retention, development, and reward the staff for enabling them to maintain a skilled, committed, and well-motivated at work. Bontis (1999) [6] viewed human capital as a person with elements of intelligence, skill, and expertise. The person may give positive to the organization's distinctive character. In contrast, the organization's human is usually based on the staff's capability in adapting the learning, changing, innovating, and providing the creative thrust in an organization where if 
the team is properly motivated, it can improve the long-term survival of the organization. The human capital may increase add value to the firm. Measurement of the importance of human capital can provide from the basis of resource-based HR strategies concerned with the development of the organization's core competencies (Wan Daud et al. (2014) [33].

\subsection{Knowledge Management}

Knowledge management contributed to a significant portion of organizational improvement (Al-halak, Al-karaghouli, Ghoneim, \& Koufopoulos, 2010) [3]. When the organization applied knowledge management at a firm, it may influence developing good human capital whereby the staff may express their knowledge, skills, and abilities to increasing organization performance (Donate \& Guadamillas, 2011) [12]. Knowledge management also has a great relationship with human capital. It can be seen as an example in the research conducted in three cases of knowledge management in the HRD office. HRD professionals can usually be considered knowledgeable when they implement knowledge management practices in their offices (Lundvall \& Nielsen, 2007) [21]. This finding showed a positive relationship between human capital and knowledge management (Jensen, Johnson, Lorenz, \& Lundvall, 2007) [15].

\subsection{Empirical Research}

\section{Human Capital and Organizational Innovation Relationship}

A valuable, rare, unique, and organized can only provide a competitive advantage of human resources to the firm. It cannot be argued that human resources are essential sources of innovation for core competitiveness, although not all staff have the value to represent human capital. Repetitive tasks are not given a significant impact and generating additional value for the organization. According to Boxall and Macky (2009) [5], firms can create human resource advantages by recruiting and retaining outstanding people. Apart from sustained comparative advantage, the human resource must be scarce and inimitable (possessing specific knowledge, skills, and abilities). Their knowledge and skills must also generate value to the customerall these judgments and ideas contained in the concept of human capital. The human capital of an organization is usually referring to the staff who have the ability of knowledge and skills to perform the job at their workplace (Subramaniam \& Youndt, 2005) [28]. Staff's knowledge refers to the ability of them to understand the products and services produced in the organization. In this sense, the unique resource available to firms is knowledge the team has, enabling them to improve performance and transform the organizational resources effectively. Furthermore, knowledge-based resources particularly crucial in ensuring a sustainable competitive advantage (McEvily \& Chakravarthy, 2002) [23] because they play an essential role in the firm's ability to innovate. Therefore, knowledge, technological skills, and experience, allowing new products to be created to gain competitive advantage.

A human resource management practice contributes a significant impact on innovation to the organization. The innovation of the products and services can be up and down depends on how the organization manages the human resources (Filippetti, 2011) [14]. Bahrami, Rajaeepour, Aghahosseini, and Bakhtiar Narsabadi (2011) [4] found that the relationship between Human resource management and organizational innovation at Iranian Universiti were significant and positive. There are also substantial multiple relations between strategic human resource management practices and administrative and technical innovation in the universities. 


\section{Human Capital and Knowledge Management Relationship}

One of the organization's approaches to ensure the staff may increase new knowledge by practicing knowledge management. The characteristics of a workforce significantly related to organizational knowledge management capability dan human resources management. Since knowledge management depends on the staff's knowledge and motivation, it seems likely that organizational practices and policies that affect the organization's human resource will be one of the significant factors affecting the organization's knowledge management. Thus, human capital may have a strong potential to be a vital driver of organizational innovation to create new knowledge (Soon \& Zainol, 2011) [31]. The organization also may take advantage of building human capital from recruiting and retaining outstanding people (Boxall \& Macky, 2009) [5].

\section{Human Capital, Knowledge Management, and Organizational Innovation}

Knowledge management represents the foremost important factor in this study. Wahyu, Hana, Troena, Nimran, and Rahayu (2013) [32] proved in their research about the connection of knowledge management and entrepreneurial orientation towards organizational innovation. This research showed that innovation performance would be affected by entrepreneurial orientation through knowledge. The finding of this research explained the contribution of human capital and knowledge management in improving innovation performance.

\section{METHODOLOGY}

Research design provides information on how research data will be collected, analyzed, and interpreted (Coolican, 2009) [10]. Given the exploratory nature of this qualitative study, a purposive sample of three (3) participants involved as participants in the research. Using a case study, a method as defined by Yin (1993) [37] regarding empirical inquiry investigates a contemporary phenomenon used as a reference. Case study strategy has a distinct advantage when "(how)" or "(why)" questions are being asked about a contemporary set of events over which the investigator has little or no control of it (Yin, 1994) [37].

Three (3) faculties of Management holding a position as a dean located in different universities were chosen in this research as a sample. The dean involvement is significant in this study due to the expert knowledge and experience they have. The rationale behind selecting only three (3) Faculties of Management is because the researchers were interested in surveying the faculty that offered the management program only located on the east coast of peninsular Malaysia.

\section{FINDINGS}

Based on the finding's session gathered between the researchers and the deans, various findings were identified. This study presents the deans' views on human capital, knowledge management, and organizational innovation among Management Faculty from three selected universities on the east coast of Peninsular Malaysia.

The deans' views on how human capital has an impact on organizational innovation. The results also able to interpret the dimensions of human capital in the context of HEI's. The researcher may state that based on the deans' view, the characteristics of human capital consists of talent, specialization, administrative and support staff, new ideas and knowledge, teamwork, IT skills, and handling stress that impacts the faculty's organizational innovation. The deans also believed human capital talent should involve participative, right-level education, and work experience. This checklist is essential to the leader when recruiting new staff in the university. For the faculty's administrative staff, they need to be exposed to job design and duties, rotation, and learning of another language to increase their innovativeness. 
The teams need to communicate their new ideas and knowledge in the meeting, group discussion, or informal conversation. The deans also can always communicate their unique approaches and expertise while dealing with their staff in administrative work. The team may express their feelings to their friends or take a holiday break purposely of handling the work stress. It benefited to the faculty by receiving new fresh ideas and having knowledgeable staff. It also may help increase and achieve organizational innovation at the faculty.

The dean's also thought that knowledge management has a connection with organizational innovation. All Deans' agreed that sharing of information, applying a new concept, valued creativity and unique thought, and recorded document for decision-making are essential components to consider when operationalizing knowledge management that could impact organizational innovation in faculty. The Deans appreciated sharing information in knowledge management meant to communicate through the mailing system, letters, meetings, and social networks. New concept applications in knowledge management can be conveyed via experiences and skills. Recognize the staff creativity and unique thought were a vital aspect of achieving organizational innovation. Besides that, the proof evidence of document for decision making also significant towards the knowledge management process, and it will contribute to the organization's innovativeness.

Deans' agreed to say that human capital could affect the faculty's organizational innovation through the knowledge management process. In this study, the deans believed the organizational innovation could be looked based on involving program and service, innovative and outstanding, student perception, industry needs, and modification of the current plan might improve the faculty's performance. Thus, the Deans agreed human capital and knowledge management are vital in running the institution to meet the objectives and increase innovation.

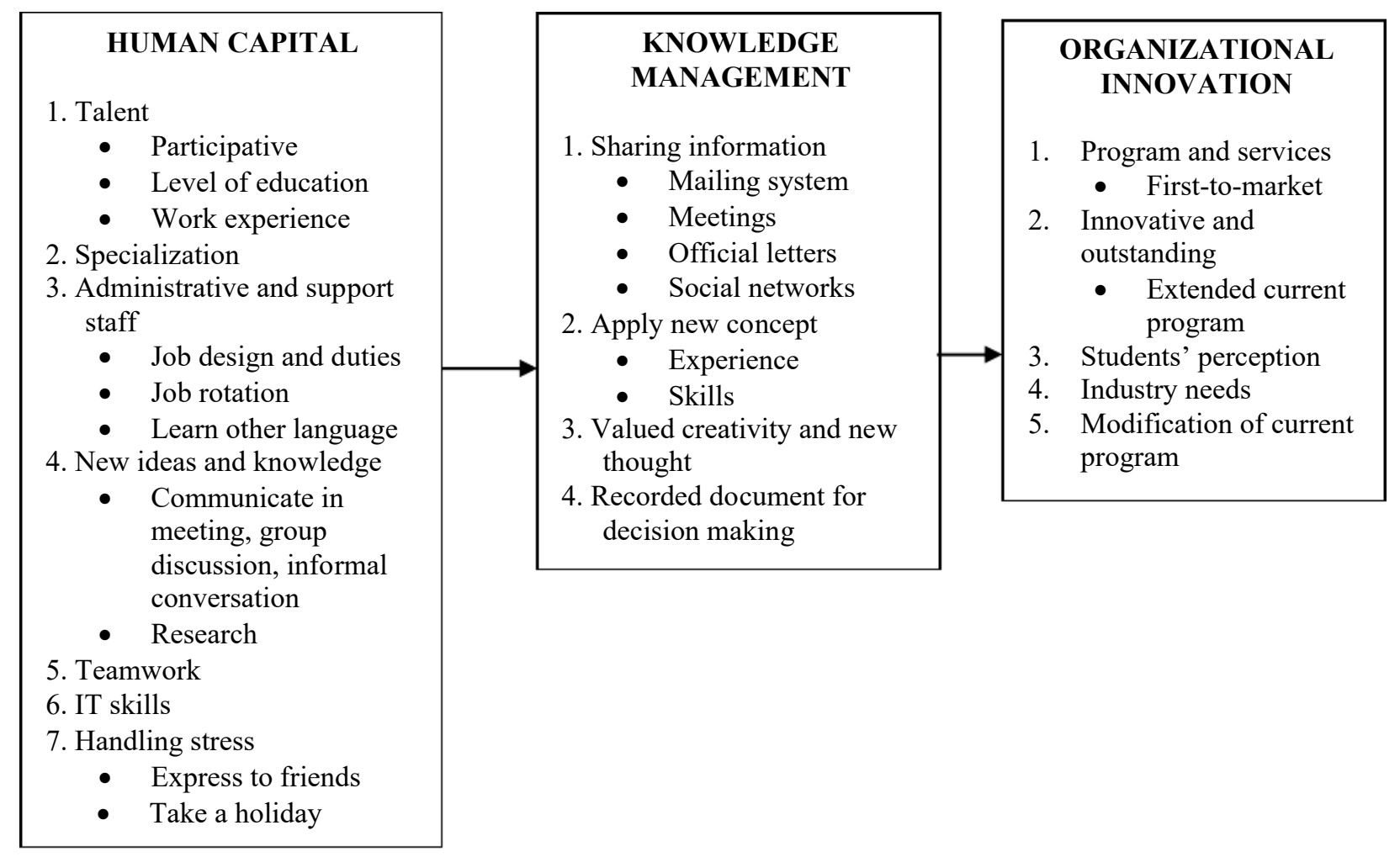

Figure 1 Summary of Findings how do human capital, knowledge management, and organizational innovation connected in HEIs. 


\section{DISCUSSION AND SUGGESTIONS}

This study affirmed that Malaysian Public Universities in the East Coast of Malaysia have performed moving towards a better innovation level. This study shows that knowledge management has a connection between human capital and organizational innovation. Having human capital (talent, specialization, administrative and support staff, new ideas and knowledge, teamwork, IT skills, and handling stress) in universities affected organizational innovation that contributes to better universities' performance. These results indicate that it is essential to have good human capital within universities to achieve the university goals. Therefore, this study has proven that human capital is beneficial to the organizational innovation of Malaysian Public Universities in the East Coast of Malaysia.

Knowledge management can be considered as one of the contributing factors towards organizational innovation. The knowledge management dimensions included sharing information, applying the new concept, valued creativity, and unique, though, and recorded documents for decision-making to influence organizational innovation. Also, it can be seen that universities will achieve higher innovation when they treat knowledge management as an essential part of universities' strategic management approach to increase their reputation.

The analysis of this study discovered that knowledge management practices were strongly interrelated and significantly influenced human capital and innovation of Malaysian Public Universities in the East Coast of Malaysia. This result is consistent with the study by Sharabati and Nour (2001) [1]. Any Strategies which will improve innovation draw attention to leaders. The developed concept of innovation strategies gives clear guidance on how to practice an effective management strategy through a combination of human capital and knowledge management for the universities to increase innovation and achieve their goals.

Finally, a positive connection between human capital and knowledge management with organizational innovation suggested that universities that adopt this strategy should experience improvements in employees' satisfaction, loyalty, retention, and universities' ranking. Excellent quality of human capital and knowledge management will harmonically generate a much better innovation and performance.

\section{CONCLUSIONS}

This study was a qualitative research design using an exploratory method. Given the exploratory nature of this study, a purposive sample of three (3) participants was used. Using a case study, a method as defined by Yin (1993) [35] as an empirical inquiry investigating a contemporary phenomenon within its real-life context was referred to as a reference. By implementing a case study strategy, it gives an advantage when "(how)" or "(why)" questions are being asked about a contemporary set of events over which the investigator has little or no control of the situation (Yin, 1994) [35].

This study's results and conclusions may also stimulate dialogue within the professional community of leadership and business researchers, consultants, and coaches, and even academia. Hopefully, the results may interlink to quality higher education in Malaysia and the GCC countries. It interpreted the goods side of organizational innovation in Malaysian Public Universities that will also be applicable in higher education institutions in the GULF as well to GULF Countries. The study also will be useful to the academic leader to encourage employees to acquire, share, and apply their knowledge to be a better organizational innovation to achieve a quality institution of higher education. Finally, the next researcher may consider splitting up innovation into technical further to examine their impact on the organization's performance. Based on the study's limitations, future research on a similar topic is recommended to improve in a particular area. First and foremost, to include all Malaysian Public Universities in the study will be of utmost advantage. The observation, 
Knowledge Management, Human Capital and Organizational Innovation as Drivers of Quality Higher Education in Malaysia: Lessons for Gulf Countries

document analysis, or surveys are strongly suggested for the future research approach besides the primary method to improve results.

\section{ACKNOWLEDGEMENTS}

We would like to convey special thanks and appreciation to our sponsor, University of Sultan Zainal Abidin (UniSZA), Kuala Terengganu for providing the financial grant to this research. Our deepest appreciation also goes to the administrators who participated in this study.

\section{REFERENCES}

[1] Abdel-Aziz Ahmad Sharabati and Abdul Nasir Ibrahim Nour (2013). The relationship between human capital development and university's business performance. European Journal of Business and Management ,5(6), 101-120.

[2] Aldisent, L. (2002). Valuing People! How Human Capital Can Be Your Strongest Asset. Chicago, IL: Dearborn Trade Publishing.

[3] Al-halak A., Al-karaghouli W., Ghoneim A., and Koufopoulos D., "Knowledge Management : Exploring the Relationship between Human Capital and Organization Structure Capital", 2010, pp.1-11.

[4] Bahrami, S., Rajaeepour, S. B. S., Aghahosseini, T., \& BakhtiarNarsabadi, H. A. (2011). Simple and multiple relations between strategic human resource management and organizational innovation at iranian universities. Asian Journal of Management Research, 2(1), pp. 74-83.

[5] Boxall, P. and K. Macky (2009). 'Research and theory on high-performance work systems: progressing the high-involvement stream'. Human Resource Management Journal,19, pp. 323.

[6] Bontis N., "National Intellectual Capital Index: A United Nations initiative for the Arab region", Journal of Intellectual Capital, 2004, pp.13-39. doi:10.1108/14691930410512905

[7] Bromand, M., \& Ranjbari, M. (2009). Strategic human resource management practices and innovation performance, with emphasis on the role of knowledge management. Journal of Human Development of the Police ,24-31.

[8] Burns, T. and Stalker, G.M. (1961) The Management of Innovation. London: Tavistock.

[9] Camarero G., (2009).“Questionnaire: impact of organizational learning and innovations on performance", pp.5-8.

[10] Coolican, H. (2009) Research Methods and Statistics in Psychology, 5th ed., Hodder, London.

[11] Damanpour F.( 1991). Organizational innovation: a meta-analysis of effects of determinants and moderators. Acad. Mgmt. J.34: 555.90

[12] Dell C. O., and Grayson C. J., "If Only We Knew What We Know", Journal of Intellectual Capital, 1998, Vol. 40(3), pp. 154-175.

[13] Donate M. J., and Guadamillas F., "Organizational factors to support knowledge management and innovation", Journal of Knowledge Management, 2011, Vol. 15(6), pp. 890-914. doi:10.1108/13673271111179271

[14] Filippetti, A. (2011) Innovation modes and design as a source of innovation: a firm-level analysis. European Journal of Innovation Management, 14(1), pp.5-26.

[15] Garcia'-Morales V.J., "Influence of Transformational Leadership on Organizational Innovation and Performance Depending On the Level of Organizational Learning in the Pharmaceutical Sector', Journal of Organizational Change Management, Vol. 21(2), pp. 188212 doi: 10.1108/09534810810856435 
[16] Ismail A., Ghani A., and Abdullah K., "Human Capital Development Practices in Malaysian Public Universities," Research Technology Management, 2011, Vol. 3(5), pp. 389-398.

[17] Jensen M. B., Johnson B., Lorenz E., and Lundvall B. Å.,(2007) "Forms of knowledge and modes of innovation", Research Policy, Vol. 36(5), pp. 680-693. Do: 10.1016/j. respol. 2007.01.006

[18] Kaplan, R. \& Norton, D. (2004). Measuring the Strategic Readiness of Intangible Assets. Harvard Business Review, Boston: MA, Harvard Business School Press. pp. 52-60.

[19] Kipley, D., Lewis, A. \& Helm, R. (2008). Achieving strategic advantage and organizational legitimacy for small and medium sized nfps through the implementation of knowledge Management. The Business Renaissance Quarterly, Fall, Vol. 3 Iss. 3. pp. 21-42.

[20] Kok J. K., \& Cheah P. K.,(2011) "The Role of the University in Fulfilling Individual Needs and Promoting a Better Society: A Malaysian Students' Perception”.

[21] Lawrence, P.R. and Lorsch, J.W. (1967). 'Differentiation and Integration in Complex Organizations'. Administrative Science Quarterly, pp.12:1-47.

[22] Lundvall B.Å., \& Nielsen P., "Knowledge management and innovation performance", International Journal of Manpower, 2007, Vol. 28 (3/4), pp. 207-223. doi:10.1108/01437720710755218

[23] McEvily, S. K. and B. Chakravarthy (2002). 'The persistence of knowledge-based advantage: an empirical test for product performance and technological knowledge', Strategic Management Journal, 23, pp. 285-305.

[24] Nonaka, I., \& Takeuchi, H. (1995). The knowledge-creating company: How Japanese companies create the dynamics of innovation. Boston: Oxford University Press.

[25] Rahimi H., Arbabisarjou A., Allameh S. M., and Aghababaei R., ("Relationship between Knowledge Management Process and Creativity among Faculty Members in the University".

[26] Rahman M. N. A., Wahab F. A., Ismail R., and Udin N.,(2013) “A Comprehensive Innovation Management Model for Malaysians Public Higher Learning Institutions", Journal of Management, 2013, Vol. 7(1),pp. 45-56.

[27] Rania, J.A \& Wan Daud, W.N. (2019) "Developing and Validating Measures of Knowledge Management Effectiveness with CFA", International Journal of Innovation, Creativity and Change, Vol. 7(7), pp. 194-211.

[28] Studies A. (2005) "The Critical Assessment of the Resource- Based View of Strategic Management: Keywords", pp. 125-150.

[29] Subramaniam, M. and M. A. Youndt (2005). 'The influence of intellectual capital on the types of innovative capabilities', Academy of Management Journal,48, pp. 450-463.

[30] Suraya Hamid and Jamaliah Mohammad Nayan. (2005). "Preliminary study of knowledge Management in a library: a case study of the National Library of Malaysia". International conference on libraries: towards a knowledge society (ICOL 2005).

[31] Tan Thai Soon and Fakhrul Anwar Zainol (2011). Knowledge Management Enablers, Process and Organizational Performance: Evidence from Malaysian Enterprises. Asian Social Science, 7 (8), 186-202

[32] Wahyu S., Hana L., Troena E. A., Nimran U., and Rahayu M. (2013). "Innovation Role in Mediating the Effect of Entrepreneurship Orientation, Management Capabilities and Knowledge Sharing Toward Business Performance: Study at Batik SMEs in East Java Indonesia", Vol. 8(4), pp. 16-27.

[33] Wan Daud, W.N, Zainol, F.A, Abdul Rahman, S.A, Yazid, A.S, Segumpan, R.A \& Mukhtar, N.D (2017). "Human Capital for Organizational Innovation in Malaysian Public Universities" World Applied Sciences Journal, Vol. 35(8), pp. 1470-1476. 
Knowledge Management, Human Capital and Organizational Innovation as Drivers of Quality Higher Education in Malaysia: Lessons for Gulf Countries

[34] Wan Daud, W.N, Abd Rahim, M, Zainol, F.A, Ismail, A.G (2018) "Leader's Qualities and Organizational Performance: A Case of Malaysian Takaful Operator" International Journal Business Performance Management, Vol. 19(2), pp. 189-208.

[35] Wan Daud, W.N, Zainol, F.A, Mansor, M. (2014) "The Effect of Knowledge Management on Human Capital towards organizational Innovation" International Journal of Social, Management, Econoics and Business Engineering, Vol. 8, No.10 pp. 3101 - 3106

[36] Yin R.K., “Application for case study research. Newbury Park: CA: Sage”, 1993.

[37] Yin R.K., "Case study research: Designs and methods (2nd ed.). Thousand Oaks", CA: Sage Publications, 1994. 